doi: 10.19090/cit.2017.31.3-12 УДК 02:82

027.52(497.11):82

Прегледни рад

\title{
Поље књижевности у јавним библиотекама у Србији
}

\author{
Драгана Сабовљев \\ dragana.sabovljev@gmail.com \\ Владимир Арсенић \\ vladimirars@gmail.com \\ Градска народна библиотека „Жарко Зрењанин”, Зрењанин
}

\begin{abstract}
Сажетак
Рад се бави односом поља књижевности и делатности јавних библиотека у Србији у историјској перспективи и савременом тренутку. Проучавајући феномен књижевног дела (али не улазећи у вредносно одређивање високе и тривијалне књижевности) и развој јавних библиотека, аутори настоје да покажу њихову блиску повезаност. Она се посматра кроз структуру фондова јавних библиотека и однос различитих чинилаца поља књижевности (писци, читаоци, издавачи). Објашњење ове везе проналази се и у дефиницији и функцијама јавних библиотека и структури њихових корисника. Представљају се промотивне активности, традиционалне манифестације и издавачка делатност засноване на књижевности. Истакнута је и образовна структура запослених и менаџмента у јавним библиотекама која такође сведочи о вези са пољем књижевности.
\end{abstract}

Кључне речи: поље књижевности, јавне библиотеке, књижевно дело, књижни фондови, промотивне активности, традиционалне манифестације, издавачка делатност, корисници, запослени, Србија

\section{Увод}

Књижевност и библиотекарство су тесно повезани, готово неодвојиви, премда она чини само један сегмент библиотечких фондова и основу за пружање услуга корисницима. Тема овога рада је однос бурдијеовског поља књижевности ${ }^{1}$ и библиотечко-информационе делатности у јавним библиотекама у Србији. То значи да су у тексту сагледани не само број књижевних дела у фондовима јавних библиотека (односно свих оних са ознаком 8 према универзалној децималној класификацији - УДК) наспрам осталих, него и односи различитих чинилаца поља књижевности (писци, читаоци, издавачи) и библиотечко-информационе делатности. Аутори се не упуштају у дефиницију књижевности као области уметничке праксе, нити вреднују књижевна дела у смислу високе и ниске, односно тривијалне књижевности, ${ }^{2}$ већ покушавају да покажу како велики део активности у јавним библиотекама своју основу налази у књижевном пољу.

\footnotetext{
1 "Простор књижевної или умешениикої заузимања йозиција, односно структурирани низ појавности друштвених чинилаца укључених у поље - књижевних или уметничких дела, наравно, али и политичких чинова исказа, манифеста, полемика итд. - неодвојив је од йоља књижевностии или умешеничких йозиција дефинисаних поседовањем одређујућих количина специфичног капитала (препознавање) и, у исто време, заузимањем одређених положаја у структури дистрибуције овог капитала. Књижевно или уметничко поље је йоље сила, али и йоље борби које тежи да промени или очува ово поље сила. Мрежа објективних односа између позиција подвргава и оријентише стратегије које они који заузимају различите положаје примењују у својој борби да заштите или унапреде своје позиције (односно заузимање тих позиција), стратегије које зависе од њихове силе и врсте положаја сваког чиниоца који заузима у односима моћи [rapports de force]". - Pierre Bourdieu, The Field of Cultural Production: Essays on Art and Literature, edited and introdu-

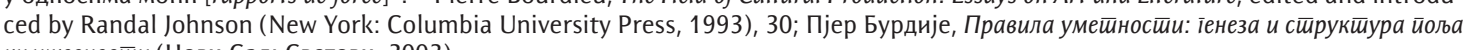
књижевносии (Нови Сад: Светови, 2003).

2 Више о томе у нпр. Rečnik književnih termina: drugo, dopunjeno izdanje, glavni i odgovorni urednik Dragiša Živković (Beograd: Nolit, 1992).
} 
Увидом у књижне фондове, делатности презентоване на веб-сајтовима јавних библиотека и њиховим страницама на друштвеним мрежама, усменом комуникацијом са колегама, проучавањем литературе, аутори полазе од чињенице да су савремене јавне библиотеке спремне и способне да корисницима понуде читав низ различитих услуга, али је однос корисника према овим установама углавном непромењен. То значи да највећи део корисничке популације лично долази у библиотеку са намером да позајми штампане монографске публикације, претежно књижевног садржаја. Чињеница је, такође, да иако савремени библиотечко-информациони системи пружају могућности онлајн претраживања, коришћења фондова и пружања информација, активно делују као сервиси грађана у разним сегментима живота, корисници јавних библиотека се најрадије опредељују за непосредан контакт са запосленима, доласком у саму зграду јавне библиотеке. У том смислу је било важно подсетити на дефиницију и функције јавних библиотека, кроз историју и у савременом тренутку, и на структуру њихових корисника.

Надаље, уважава се чињеница да понуду већине издавачких кућа чине дела из књижевности. Откуп Министарства културе Републике Србије највећим делом потиче из ове области, те је и то разлог што се библиотечки фондови, када су у питању штампане монографске публикације, попуњавају управо делима из књижевности. Слично је и са штампаним периодичним публикацијама - у јавне библиотеке у Србији највећим делом стижу књижевни часописи. Када су у питању промотивне активности јавних библиотека, аутори примећују да су највише посећене књижевне манифестације (промоције књига и часописа, радионице итд). Велики део ових активности представљају оне намењене деци, али се такође заснивају на књижевним делима из области дечје књижевности. Јавне библиотеке у Србији имају веома развијену издавачку делатност, те је, увидом у њихову продукцију, јасно и очигледно да је, у већини случајева, реч о објављивању монографских публикација књижевне садржине. Слично је и са периодичним публикацијама у издању јавних библиотека. На крају, посматрана је и образовна структура запослених, као и менаџмента и може се рећи да велики број свршених студената различитих студијских група језика и књижевности посао налази управо у јавним библиотекама.

\section{Однос књижевности и јавних библиотека у историјској перспективи}

Књижевност се током историје различито дефинисала, ${ }^{3}$ али је свакако неодвојива од језика и од његове материјализације у виду текста који тражи да буде на известан начин фиксиран, чак и када је реч о усменој књижевности. У том смислу, постојање књижевности је незамисливо без постојања медија кроз који се она преноси, а медији су се чували и чувају се у библиотекама.

Првобитне библиотеке су настајале као чувари религијских, административних, привредних и књижевних записа. Међутим, кроз историју ова грађа почиње да бива предметом проучавања различитих научних дисциплина, међу њима и филолошких. 3бог тога се добар део писаног наслеђа из прошлости у данашње време посматра као део књижевности, чак иако није настајао као књижевно дело. Он је опстао и остао сачуван до данас управо захваљујући библиотекама, најпре грчким, а затим хеленистичким, римским, ранохришћанским, арапским, средњовековним манастирским, ренесансним и тако даље. Те библиотеке нису биле намењене најширем слоју становништва. Оне су настајале у затвореним круговима, што због изражене класне природе друштава у којима се јављају, што због веома малог броја писмених људи. ${ }^{4}$

Тек са појавом штампе, половином 15. века, долази до ширења писмености, а књига као преносилац знања, информација или књижевних садржаја постаје доступнија. „За потребе новог слоја читалачке публике, која нема великог интереса за научна дела на грчком и

\footnotetext{
Isto.

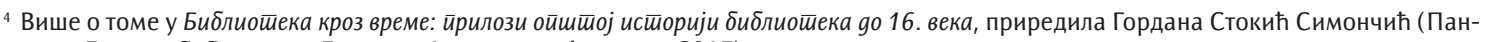
чево: Градска библитоека; Београд: Филолошки факултет, 2017).
} 
латинском језику, штампају се и издају корисне, јефтине, лако разумљиве и популарне књиге. Нека позната књижевна дела преводе се на народне језике и приређују у облицима који су приступачнији градском становништву. ${ }^{5}$

Важно је истаћи да након појаве штампе долази до постепене професионализације у пољу манипулације књигама, па се тако издвајају штампарије, издавачке куће, књижаре и књижарски ланци. Ипак, куповина, поседовање, читање књига представљали су привилегије виших друштвених класа. Из тежње да се књига учини доступном што ширем слоју становништва потекла је идеја о оснивању друштава за читање у Француској, Немачкој, Енглеској и другим европским земљама. „Иако се кабинети за читање у Француској јављају већ почетком XVIII века, они ће тек у првих пет деценија XIX века доживети свој врхунац, а затим ће почети да се смањује њихов значај и популарност. Настали у време када су књиге, новине и часописи били сувише скупи за већину читалаца, када се у литератури појављује роман као нови књижевни облик, а јавне библиотеке још не постоје - кабинети за читање ће имати изванредног успеха и бројну читалачку публику."

Премда се неки облици и функције јавних библиотека могу наћи и дубље у историји, почев од Грчке и Старог Рима, тек средином 19. века у англо-америчким земљама настају прве модерне јавне библиотеке. Оне су последица развоја грађанског друштва и његових политичких идеала просветитељства и демократије, као и образовања доступног најширем слоју друштва. „Њихове збирке имале су универзални карактер и биле су бесплатно доступне свим категоријама читалаца. У прво време назване су free public library (бесплатне јавне библиотеке), а касније public library (јавне библиотеке). Кључна терминолошка одредница упућује на појам јавности као конститутивног елемента модерног грађанског и демократског друштва у којем су јавне институције у начелу свима доступне под једнаким условима. Једна од првих америчких дефиниција јавних народних библиотека гласи да су то библиотеке отворене јавности, то јест публици."7 Занимљиво је приметити да су отпор оснивању јавних библиотека пружали издавачи и књижари у страху да ће опасти продаја књига. Међутим, догодило се управо супротно, библиотеке су се показале као највећи промотери књига и читања, тако да је продаја књига заправо скочила, а саме јавне библиотеке су их куповале за попуњавање својих фондова. ${ }^{8}$

У првим деценијама 19. века почиње културни развој Србије ослобађењем од турске власти и успостављањем кнежевине 1815. године. Елементи грађанског живота међу Србима постојали су на територијама под аустроугарском управом, док је народ под турском влашћу живео у феудалном друштвеном уређењу. У Војводини се суочавао са опасношћу асимилације и губитка националног и културног идентитета, иако су економски и политички услови били прилично повољни. Припадници грађанског друштва из ових крајева често су се образовали у великим европским центрима (Беч, Пешта, Грац, Лајпциг, Падова итд) и одатле доносили нове културне вредности. Са друге стране, народ на територији под турском управом живео је у тешким економским условима, био је претежно неписмен, није имао своје школе, нити било какве друге културне институције, штампарије или књижарске мреже. Оне почињу да се оснивају тек ослобођењем од Турака. На формирање школа, читалишта и библиотека утицаја су имали и образовани сународници са севера, позвани да помогну њиховом конституисању. Такође, публикације потребне за описмењавање и просвећивање народа штампане су у иностранству, одакле су почели да пристижу и новине и часописи.

У 19. веку у Србији радило је 95 читалишта која су „еволуирала од првобитног друштва за читање новина, међусобног састајања и размене информација, преко институције за образовање

\footnotetext{
${ }^{5}$ Жељко Вучковић, „Закључак или зашто је штампарство заувек преокренуло историју библиотека”, у Библиошека кроз време, 209.

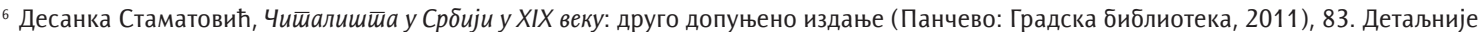
о организованим облицима читања у европским земљама видети поглавље „Главне карактеристике читаоница на европском тлу”. ${ }^{7}$ Жељко Вучковић, Јавне библиошеке и јавно знање (Нови Сад: Библиотека Матице српске; Футура публикације, 2003), $21-22$.

${ }^{8}$ David H. Tucker et al., "History of Publishing", in Encyclopedia Britannica, https://www.britannica.com/topic/publishing (preuzeto 2. 9. 2017).
} 
и просвећивање народа и културних центара широко заинтересованих за сакупљање народног блага и музејских вредности, подизање позоришта, оснивање певачких дружина, покретање новина и јачање библиотека, до политичких центара ангажованих на буђењу и неговању националне свести, покретању акција за слободу штампе и увођење реформи, давању моралне и материјалне подршке борби војвођанских Срба и окупљању напредних снага око идеје ослобођења српског народа од туђинске власти. ${ }^{\prime 9}$ Њихове фондове сачињавале су монографске и серијске публикације на српском и страним језицима. Удео књижевних дела није занемарљив и она су служила не само за образовање, него су се изводиле драме, певала и читала поезија, а „сакупљање народног блага" подразумевало је записивање и објављивање усмене народне књижевности, чији је значај при буђењу националне свести и грађењу идентитета Вук Караџић уочио и предано радио на њеној популаризацији.

Прва јавна библиотека основана је у Крагујевцу 1866. године и означила је почетак рађања ових институција, пониклих на традицијама читалишта, „библиотека које оснивају и финансирају локални органи власти, а не приватна лица, библиотека које су доступне свим грађанима уз минималну надокнаду, које имају организован фонд библиотечке грађе и стручно лице које у њима ради". ${ }^{10}$ Период од почетка 20. века обележило је оснивање најзначајнијих јавних библиотека на иницијативу државе, као и виђенијих појединаца и теоријско утемељење њихове делатности. ${ }^{11}$ Њихово деловање су прекинула два светска рата која су донела до тада невиђена разарања. Период од завршетка Другог светског рата до деведесетих година 20. века и грађанског рата на подручју бивше Социјалистичке Федеративне Републике Југославије донео је убрзани развој библиотечке струке, утемељење формалног образовања библиотекара, законско регулисање професије и установљавање научних основа делатности. Такође је представљао и период материјалног благостања, када се граде зграде јавних библиотека и попуњавају њихови фондови. Од деведесетих година 20. века до данас, библиотекарство је признато као научна дисциплина, делују две катедре за формално образовање библиотекара (на Филолошком факултету у Београду и на Педагошком факултету у Сомбору), а убрзани развој информационих технологија донео је велике промене у раду јавних библиотека, када се њихове функције прикупљања, чувања, обраде и давања на коришћење библиотечке грађе мењају, а оне постају информациони центри и сервиси различитих потреба грађана. ${ }^{12}$

Романтизам и буђење националне свести, након Француске буржоаске револуције, доводе до промене улоге књижевности. Она постаје простор за идентитетске политике, кохезиона сила која уједињује народ. Сваки жанр у томе има своју улогу, а роман посебно. Иако не постоји начин да се докаже јасна веза између јачања романа и отварања читаоница, читалишта и јавних библиотека, индикативно је да њихова појава коинцидира, односно они се развијају с појавом грађанског друштва.

Истовремено, не треба изгубити из вида и чињеницу да су читаонице, читалишта и јавне библиотеке били места која су, поред образовне, културне и политичке, вршила и функцију забаве. Другим речима, људи нису долазили у њих само да би читали новине, гледали представе, слушали и певали песме које су будиле осећај припадања одређеном народу или друштвеном слоју, већ и да би у њима провели своје слободно време које, од средине 19. века наовамо, више није привилегија богатих. То значи да су читаонице, читалишта и јавне библиотеке посећивани да би се људи просто речено - забавили. Због тога се у њима налазе и дела такозване

\footnotetext{
9 Десанка Стаматовић, Нав. дело, 14.

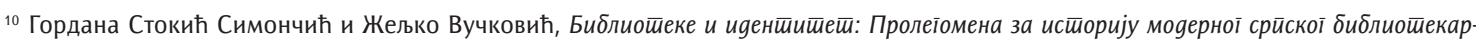
сиива (Панчево: Градска библиотека; Нови Сад: Филозофски факултет, 2012), 49.

11 Детаљније о томе у Бранка Драгосавац, Јавне библиошеке у Србији og 1901. go 1918. іоgине (Панчево: Градска библиотека; Ниш: Народна библиотека "Стеван Сремац"; Неготин: Народна библиотека „Доситеј Новаковић”, 2016).

12 Више у Гордана Стокић Симончић и Жељко Вучковић, „Основни правци развоја библиотекарства у Србији 1945-1990”, у Библи-

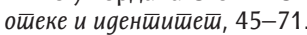


тривијалне књижевности. Њихова појава је омогућена развојем и појефтињењем штампе, односно повећањем тиража брошираних публикација, серијализацијом у часописима и алманасима и ширењем читалачке публике.

\section{Поље књижевности и јавне библиотеке у Србији}

У IFLA/UNESCO смернииама за развој јавних библиотеека оне су дефинисане као организације које оснива и издржава локална заједница, које су доступне свим грађанима и нуде им приступ знању, информацијама и производима људског духа на различитим медијима. ${ }^{13}$ Јавна библиотека је најдемократскији тип библиотеке јер је намењена најширем слоју становништва, али и специфичан, онолико колико је свака заједница у којој делује посебна и самосвојна. Она прикупља, чува и презентује културна достигнућа средине у којој настаје. С друге стране, улога јој је да препозна шире потребе заједнице и да на све начине изађе у сусрет корисницима.

Јавне библиотеке као институције у којима се сакупљају и чувају информације које би требало одмах да буду на располагању корисницима имају, између осталих, и следеће задатке: стварање и неговање читалачких навика код деце од раног узраста; пружање могућности за лични креативни развој; подстицање маште и креативности код деце и младих; повећање свести о културном наслеђу, разумевања уметности, научних достигнућа и открића; унапређивање дијалога међу културама и неговање културне разноликости и, коначно, подршку и учествовање у књижевним активностима и програмима намењеним свим старосним групама и покретање таквих активности, ако је неопходно. ${ }^{14}$ Ови задаци, заправо, показују везу између јавних библиотека и књижевности јер се код деце од најранијег узраста подстичу и негују читалачке навике, машта и креативност управо читањем најразличитијих књижевних дела прилагођених њиховом узрасту. Потом, нарочито у мултикултуралним и мултиетничким срединама, поље књижевности служи да се покаже разноликост култура, али и њихов суживот у једној средини, као и за повећавање свести о културном наслеђу. Књижевност показује трајање и припадност култури. Најизраженија веза је управо у организовању и одржавању програма и различитих активности намењених најширем кругу корисника.

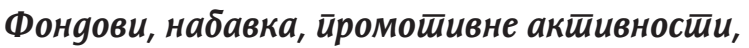

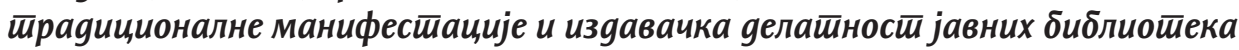

Према подацима из Централног регистра библиотека Србије и из базе Мрежа библиотека Србије (МБС) укупан број јавних библиотека у Србији износи $564 .{ }^{15}$ Укупан удео фонда књижевности у свим јавним библиотекама Србије износи $77,2 \% .{ }^{16}$ Ове податке је могуће тумачити испуњавањем потреба и жеља корисника, али и понудом издања доступних библиотекама. Већину продукције издавачких кућа чине управо књижевна дела. Довољно је погледати њихове каталоге, па уочити да највећи број објављених публикација чине дела из области књижевности. То повлачи за собом и стање у фондовима јавних библиотека, које и немају велику могућност избора када је набавка грађе у питању.

${ }^{13}$ IFLA/UNESCO Смернище за развој јавних библиоешека (Београд: Народна библиотека Србије; Библиотека града Београда, 2005$), 9$.

${ }_{14}$ IFLA/UNESCO Манифести за јавне библиоетеке, https://www.ifla.org/files/assets/public-libraries/publications/PL-manifesto/pl-manifesto-sr.pdf (преузето 3. 9. 2017).

${ }^{15}$ Сви подаци искоришћени у овом раду добијени су од Матичне службе Народне библиотеке Србије. „Обухваћени су сви облици јавних библиотека: општинске/градске јавне библиотеке, огранци јавних библиотека у насељима (организационо налазе се у саставу општинских јавних библиотека, дакле нису самосталне установе/правна лица), месне јавне библиотеке (самосталне установе, правна лица), библиотеке у саставу културних центара и домова културе, јавне библиотеке општег типа у предузећима (налазе се у саставу различитих организација, предузећа, фабрика, удружења, установа...)."

16 „Треба ипак имати у виду да нису све библиотеке дале податке о УДК структури фонда (за око 30\% укупног фонда није дата структура по УДК). Укупан број књига у свим јавним библиотекама на крају 2016. износио је 13.934.530 књига. Податак о УДК структури дат је за 9.288.208 књига (од тога 7.168.559 књига, укључујући и дечје, припада групи 8)." 
Илустративан пример представља листа понуђених наслова на Конкурсу откупа за набавку публикација за јавне библиотеке у Србији, који се сваке године понавља и на којем опет велику већину чине управо књижевна дела. Нажалост, због веома лоше финансијске ситуације у библиотекама, оне су принуђене да своје фондове допуњују махом на оваквим и сличним конкурсима. ${ }^{17}$

Узму ли се у обзир промотивни и остали програми (трибински, радионичарски, предавања...) које јавне библиотеке с мањом или већом редовношћу обављају унутар своје делатности, запажа се врло слична ситуација. Велика већина програма посвећена је промоцији књижевних дела и њихових аутора. У једном интервјуу, Филип Давид, добитник НИН-ове награде за 2015. годину, изјавио је: „У мањим местима по унутрашњости Србије све је замрло, нема посла, велике фирме су се угасиле, али библиотеке постоје и ту се окупљају људи. Захваљујући њима постоји културни живот и у малим срединама. Апеловао сам, кад год сам био у прилици и на власт и на оне који кроје културну политику да помогну библиотекама..."18 Без обзира што ово није изолован случај, већ пре правило, јавне библиотеке у Србији нуде много различитих садржаја који не потичу превасходно из поља књижевности. Ипак, однос корисника и јавних библиотека је и даље такав да они долазе у ове установе, у личном контакту са запосленима врше избор штампаних монографских публикација најчешће из књижевности, стога је логично што у највећем броју прате програме који се баве промоцијом управо књижевних дела и аутора.

Такође, готово да нема јавне библиотеке у Србији која нема неки традиционални програм намењен управо промовисању књижевности и књижевног стваралаштва намењен различитим узрасним групама. „Изложбе, промоције књига, предавања и трибине организује $98 \%$ јавних библиотека у Србији, а посебно одељење или службу чији је задатак културно-образовна делатност организовало је 45\% библиотека. Према извештајима библиотека, које статистички евидентирају посећеност културно-образовних програма и манифестација, одрасли корисници највише су заинтересовани за различита предавања и трибине које библиотеке организују у сарадњи са еминентним стручњацима за одређену област, за промоције књига и књижевне програме, као и за традиционалне вишедневне манифестације различитог карактера. Деца су најчешћи корисници едукативних и креативних радионица, а готово све библиотеке бележе изузетно велики одзив деце школског узраста приликом општинских и окружних смотри рецитатора или дружења са дечјим писцима. Поводом 'Дечије недеље' коју скоро све библиотеке обележавају почетком октобра сваке године, организују се бројни књижевни сусрети деце са завичајним писцима и песницима."19

Велики број јавних библиотека у Србији има веома развијену издавачку делатност. Она је настала првенствено из потребе да се јавности представи завичајна култура и знаменити појединци који су је обележили, а потом се показало да је продаја сопствених издања јавним библиотекама омогућила пристојан приход за потребе њихових активности и набавку нових публикација. Увидом у књижну продукцију јавних библиотека, намеће се закључак да је издавачка политика највише усмерена ка објављивању књижевних

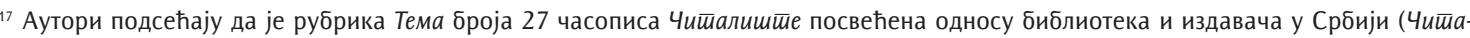
лишиее: научни иасойис за шеорију и йраксу библиошекарсивва година XIV, број 27 (новембар 2015)). Том приликом објављен је записник са трибине „Набавна политика библиотека и спровођење откупа публикација за библиотеке Министарства културе и информисања Републике Србије” одржане у Градској библиотеци у Панчеву 7. септембра 2015. године.

${ }^{18}$ Filip David, „U manjim mjestima umire sve sem biblioteka”, Glas Srpske, 6. 1. 2017., http://www.glassrpske.com/kultura/vijesti/FilipDavid-za-Glas-Srpske-U-manjim-mjestima-umire-sve-sem-biblioteka/lat/226520.html (preuzeto 6. 9. 2017).

${ }^{19}$ Марина Митрић, „Коришћење фондова и услуга јавних библиотека у Србији”, Савремена библиошека година XXVII, бр. 32 (2015): 26. Ауторка надаље набраја традиционалне вишедневне културне манифестације са веома уочљивим књижевним садржајима: „Матићеви дани у Ћуприји, Дисово пролеће у Чачку, Мајски дани књиге у Панчеву, Дани Дежеа Костолањија и Дани Балинта Вујкова у Суботици, Дани Настасијевића у Горњем Милановцу, Вељкови дани у Сомбору, Догађања у дворишту у Ваљеву, Фестивал хумора за децу у Лазаревцу, Жички духовни сабор у Краљеву, Летњи фестивал књиге у Аранђеловцу, Дани српскога духовно преображења у Деспотовцу, Рашке духовне свечаности, Мајски дани културе у Ариљу", а ми додајемо Песничку штафету, Читалачку значку или Књижевни конкурс часописа Улазница у Градској народној библиотеци „Жарко Зрењанин”, Стиховизију у Библиотекама у Смедереву и Панчеву, Једну књигу - један град Градске библиотеке у Панчеву, многобројне књижевне клубове и школе креативног писања у Димитровграду, Врању, Ужицу и многе друге. Детаљније о дечјим програмима и традиционалним

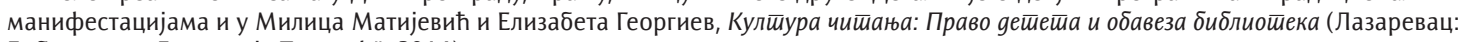
Библиотека „Димитрије Туцовић”, 2014)
} 
дела. ${ }^{20}$ Показало се, такође, да оне, будући да нису првенствено усмерене тржишно, могу себи да дозволе да објављују поезију, есејистику, теорију, путописе и друге књижевне родове и врсте које комерцијални издавачи углавном заобилазе. У оквиру издавачке делатности јавних библиотека излазе и неки од најзначајнијих и најутицајнијих књижевних часописа. ${ }^{21}$ Јасно је да без њих, односно јавних библиотека као издавача, нажалост, у Србији готово да и не би постојала књижевна сцена.

\section{Зайослени и меначменӣ у јавним библиоиеекама}

Погледом на менаџмент и структуру запослених, јасан је закључак да се и у том сегменту јасно указује нераскидива веза између књижевности и библиотекарства. ${ }^{22}$ Велики број запослених, као и садашњих и бивших директора јавних библиотека у Србији, долази са катедри за књижевност и језик, или се бави књижевним радом као песници, писци или критичари. На Филозофском факултету Универзитета у Источном Сарајеву постоји студијски програм Општа књижевност и библиотекарство, а на Филозофском факултету у Сарајеву Одсјек за компаративну књижевност и библиотекарство, што сведочи о томе да и унутар образовног система постоји свест о вези између библиотекарства и књижевности.

Овај тренд није само карактеристичан за библиотеке у Србији. Многи познати књижевници, попут Гетеа, браће Грим, Хелдерлина, Стриндберга, Музила, Пруста, Љосе, Борхеса, били су библиотекари. ${ }^{23}$

\section{Закључна разматрања}

Податак добијен од Матичне службе националне библиотеке да 77,2\% фондова јавних библиотека чине публикације из области књижевности већ сам по себи показује да су активности библиотека умногоме везане за ову област. Толико снажна веза између библиотечко-информационе делатности и само једне области људскога знања може да буде пуна могућности, али и препрека.

Јавне библиотеке, настале половином 19. века, у Србији нешто касније, као резултат просветитељских тежњи ка образовању и знању доступном свим слојевима становништва под једнаким условима, најдемократскији су тип библиотека. Као институције које оснива, финансира и подржава заједница, у обавези су да задовоље потребе њених чланова, а као чувари производа људског духа, да их презентују на свима доступан начин. Њихова традиционална улога сакупљача и чувара научних и уметничких продуката материјализованих у виду разних врста публикација, развојем информационих технологија проширена је на пружање и размену информација и комуникацију. Књижевност је у том контексту само једна од области у чијим оквирима би ова комуникација са корисницима требало да се одвија.

${ }^{20}$ Издавачкој делатности библиотека је био посвећен и Библионет: стручно-научни скуп Заједнице матичних библиотека Србије 2013. године у Смедереву. Тема најновијег броја Країујевачкої иишалишта, листа Народне библиотеке „Вук Караџић” у Крагујевцу, година XXII, број 43 (јун 2017), такође је издавачка делатност у библиотекама. Овом приликом морамо да издвојимо издавачку продукцију Градске библиотеке у Панчеву која је специфична по томе што се определила да објављује монографске и серијске публикације из области теорије и праксе библиотекарства, иако има значајан број публикација из области завичајног књижевног стваралаштва. Градска народна библиотека „Жарко Зрењанин” из Зрењанина, са друге стране, своју издавачку делатност највише је ослонила на деловање Фонда „Тодор Манојловић”, чији је један од задатака и додела Награде за модерни уметнички сензибилитет ауторима који имају обавезу да објаве књигу у оквиру библиотеке, тј. едиције Феникс. На овај начин објављена су дела најеминентнијих савремених књижевника.

${ }_{21}$ Библиотека „Стефан Првовенчани” у Краљеву издаје часопис Повеља, у Крагујевцу Народна библиотека „Вук Караџић” часопис Кораии, у Зрењанину у Градској народној библиотеци излази Улазнииа, у Сомбору у Градској библиотеци „Карло Бијелицки”, До-

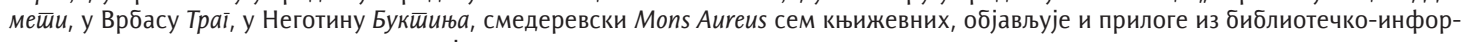
мационе делатности, што га чини значајним изузетком, да поменемо само неке.

22 Иако су се аутори овога рада ограничили на јавне библиотеке у свом проучавању, овом приликом се мора издвојити податак да три кровне институције српског библиотекарства на свом челу имају књижевнике: управник Народне библиотеке Србије је Ласло Блашковић, Универзитетске библиотеке „Светозар Марковић” у Београду Александар Јерков, а Библиотеке Матице српске Селимир Радуловић, сва тројица признати и познати књижевници.

${ }^{23}$ Детаљније у Anhel Esteban, Pisac u svom raju: Trideset velikih pisaca koji su bili bibliotekari (Beograd: Dereta, 2016) 
Као прилично виталне установе, способне да се прилагоде разним променама друштвених околности, јавне библиотеке су се потрудиле да одговоре на све захтевније потребе корисника. У конкуренцији медија преко којих информација може да се добије брже и једноставније, требало је пронаћи начин да се докаже да услуге које пружају не могу да се добију на другом месту толико ефикасно и квалитетно. Да би остале међу креаторима културне политике једне заједнице, своје активности су морале да прилагоде новом сензибилитету публике коју желе да привуку. 3бог тога им никако не иде у прилог чињеница да већину корисника чине они који и даље имају традиционални однос према установи у коју долазе да би, у непосредном контакту са запосленима, бирали штампане монографске публикације књижевног садржаја. Такви корисници такође имају своје потребе, те је разумљиво што је набавна политика јавних библиотека конципирана тако да им се обезбеде оне публикације које желе да виде на полицама. Са друге стране, понуда комерцијалних издавачких кућа најбогатија је у области књижевности.

Чињенице да су јавне библиотеке у све лошијем материјалном положају, да им Закон о јавним набавкама усложњава процес набавке нове грађе за фондове и да су упућене на откуп публикација који спроводи Министарство културе и информисања Републике Србије у чијој понуди су већином књижевна дела, такође објашњавају како су дошле у ситуацију да им она у толиком проценту чине саставни део фондова. Због тога, у својим представљањима на вебстраницама, на друштвеним мрежама, у медијима, приликом усмене комуникације, истичу и све друге аспекте свога пословања, стављају у први план садржаје и публикације из других области људског знања, не би ли привукле и оне потенцијалне кориснике чија интересовања нису окренута књижевности.

Позитиван аспект овог односа представља чињеница да је књижевност, од свога настанка, свих жанрова и врста, веома привлачна најширем кругу корисника и пружа велике могућности комуникације и интеракције између оних који је стварају, чувају и представљају и оних којима је намењена. Деца стичу навике читања управо преко књижевних дела намењених њиховом узрасту, а један од прокламованих циљева сваке јавне библиотеке је и стварање популације која ће користити њене услуге целога живота. Са друге стране, у данашње време је укорењено мишљење „да се ништа не чита” и очигледно је да се у јавним библиотекама смањује број корисника, те је један од њихових изазова да нађу начин да их привуку, а књижевност нуди велику могућност осмишљавања таквих садржаја.

Оно што је такође веома важно, а што се помало потискује и занемарује у корист едукативних функција јавних библиотека, јесте и чињеница да њихови фондови служе за забаву корисницима, а простор за провођење слободног времена. Иако савремени библиотечко-информациони системи нуде могућности комуникације између корисника и садржаје који их привлаче да бораве у њиховим зградама, не треба сметнути с ума да је већи део фондова штампани, и то монографске публикације, књижевног садржаја. У овом сегменту развија се расправа у вези са утицајем запослених на позајмним одељењима на читалачки укус корисника, са утицајем корисника на набавну политику јавних библиотека, али и са чињеницом колико лоше по библиотеку може да буде ако је мотив за коришћење фонда искључиво забаван. ${ }^{24}$ Аутори овога рада су се оградили од вредносног одређивања, тј. књижевност нису делили на високу и тривијалну, иако су свесни какве публикације улазе у фонд библиотеке и које изазивају интересовање најширег круга корисника. Сматрају да оваква расправа захтева посебну пажњу и није је могуће ваљано аргументовати уколико није предмет посебног рада. Подсећају да је дискусија увек актуелна и води се сваки пут када се спроводи ткуп публикација за библиотеке. Надаље, промотивне активности, традиционалне манифестације и издавачка делатност јавних библиотека показали су да се њима у највећој мери представљају књижевна дела, или, ако им и нису примарна тема, чине основу за успешно представљање.

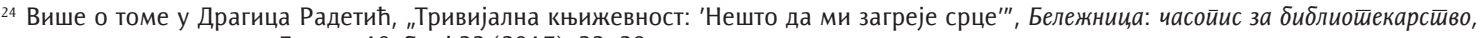
књижевносии и кулишуру Година 19, број 33 (2017): 33-38.
} 
Што се запослених и менаџмента тиче, чињеница да јако велики број свршених студената разних група језика и књижевности посао налази управо у јавним библиотекама има своје позитивне и негативне аспекте и у стручној јавности у Србији изазива непрекидне и жучне полемике. ${ }^{25}$ Требало би подсетити да су развоју библиотекарства и као струке и као науке неизмерно допринели и они који нису библиотекари по формалном образовању. С друге стране, уколико постоје две катедре за библиотекарство и информатику у Републици Србији, није ни јасно ни логично да они који са њих одлазе као дипломирани библиотекари немају предност приликом запошљавања у библиотекама. Овде се може наћи објашњење у стереотипу који струка још увек није успела да превазиће, ${ }^{26}$ а то је да запослени у библиотекама седе на удобним местима, у интимној атмосфери и читају књижевна дела, као и то да дипломирани професори књижевности и филолози најуспешније препоручују књиге корисницима. У свему томе има и део истине, јер би задатак запослених и требало да буде темељно познавање фондова, међутим они јако добро знају колико то представља мали део посла који су дужни да обављају. Нажалост, докле год овај стереотип постоји, знак је да нису довољно учинили да своју професију представе јавности.

Сагледавајући све наведене аспекте односа књижевности и јавних библиотека аутори овога рада су консултовали одабрану литературу, веб-странице и странице на друштвеним мрежама јавних библиотека, податке Матичне службе Народне библиотеке Србије и велики број колега из библиотека, али и из поља књижевности. Бавећи се односом књижевности и делатности јавних библиотека у Републици Србији у историјској перспективи и савременом тренутку, нису имали намеру да покажу како су и јавне библиотеке један од чинилаца поља књижевности, али се овај закључак наметнуо. Задатак јавних библиотека би, у овом контексту, требало да буде да овај статус искористе, а не да га негирају, јер могућности које он пружа, посебно у сегменту представљања и популарисања, може да послужи да и друге активности постану видљиве најширем кругу постојећих, али и потенцијалних корисника.

\section{Литература и извори:}

1. Biblioteka kroz vreme: prilozi opštoj istoriji biblioteka do 16. veka. Priredila Gordana Stokić Simončić. Pančevo: Gradska biblioteka; Beograd: Filološki fakultet, 2017.

2. Bourdieu, Pierre. The Field of Cultural Production: Essays on Art and Literature. Edited and introduced by Randal Johnson. New York: Columbia University Press, 1993.

3. Burdije, Pjer. Pravila umetnosti: geneza i struktura polja književnosti. Novi Sad: Svetovi: 2003.

4. David, Filip. „U manjim mjestima umire sve sem biblioteka”. Glas Srpske, 6. 1. 2017. http://www. glassrpske.com/kultura/vijesti/Filip-David-za-Glas-Srpske-U-manjim-mjestima-umire-sve-sembiblioteka/lat/226520.html (preuzeto 6. 9. 2017).

5. Dragosavac, Branka. Javne biblioteke u Srbiji od 1901. do 1918. godine. Pančevo: Gradska biblioteka; Niš: Narodna biblioteka "Stevan Sremac"; Negotin: Narodna biblioteka "Dositej Novaković", 2016.

6. Esteban, Anhel. Pisac u svom raju: Trideset velikih pisaca koji su bili bibliotekari Beograd: Dereta, 2016.

7. IFLA/UNESCO Manifest za javne biblioteke. https://www.ifla.org/files/assets/public-libraries/ publications/PL-manifesto/pl-manifesto-sr.pdf (preuzeto 3. 9. 2017).

8. IFLA/UNESCO Smernice za razvoj javnih biblioteka. Beograd: Narodna biblioteka Srbije; Biblioteka grada Beograda, 2005.

\footnotetext{
${ }_{25}$ Више о томе у Драгана Сабовљев, „Библиотечко законодавство и положај запослених у јавним библиотекама у Србији”, Чишали-

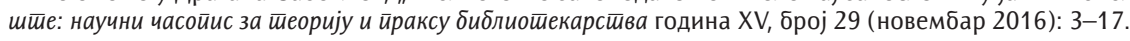

${ }^{26}$ О стереотипима о библиотекама и библиотекарима у уметничкој књижевности и популарној литератури пишу Милица Матијевић и Виолета Ђорђевић у овом броју Чишалишйа. Видети и Jelena Jaćimović i Ružica Petrović, „Stereotipi bibliotekara u javnosti, popularnoj kulturi i stručnoj literaturi", Infoteka god. 15, 1 (2014): 56-66, http://infoteka.bg.ac.rs/pdf/Srp/2014/INFOTHECA_XV_1_2014_56-66.pdf (preuzeto 1.9. 2017).
} 
Сабовљев Д. и др. „Поље књижевности у јавним библиотекама у Србији”, 3-12

9. Jaćimović, Jelena i Ružica Petrović. „Stereotipi bibliotekara u javnosti, popularnoj kulturi i stručnoj literaturi". Infoteka god. 15, 1 (2014): 56-66. http://infoteka.bg.ac.rs/pdf/Srp/2014/INFOTHECA_ XV_1_2014_56-66.pdf (preuzeto 1.9. 2017).

10. Matijević, Milica i Elizabeta Georgiev. Kultura čitanja: Pravo deteta i obaveza biblioteka. Lazarevac: Biblioteka "Dimitrije Tucović", 2014.

11. Mitrić, Marina. „Korišćenje fondova i usluga javnih biblioteka u Srbiji”, Savremena biblioteka godina XXVII, br. 32 (2015): 22-29.

12. Radetić, Dragica. „Trivijalna književnost: 'Nešto da mi zagreje srce'". Beležnica: časopis za bibliotekarstvo, književnosti i kulturu Godina 19, broj 33 (2017): 33-38.

13. Rečnik književnih termina: drugo, dopunjeno izdanje. Glavni i odgovorni urednik Dragiša Živković Beograd: Nolit, 1992.

14. Sabovljev, Dragana. „Bibliotečko zakonodavstvo i položaj zaposlenih u javnim bibliotekama u Srbiji”. Čitalište: naučni časopis za teoriju i praksu bibliotekarstva godina XV, broj 29 (novembar 2016): 3-17.

15. Stamatović, Desanka. Čitališta u Srbiji u XIX veku: drugo dopunjeno izdanje. Pančevo: Gradska biblioteka, 2011.

16. Stokić Simočić, Gordana i Željko Vučković. Biblioteke i identitet: Prolegomena za istoriju modernog srpskog bibliotekarstva. Pančevo: Gradska biblioteka; Novi Sad: Filozofski fakultet, 2012.

17. Tucker, David H., Philip Soundy Unwin and George Unwin. "History of Publishing". In Encyclopedia Britannica. https://www.britannica.com/topic/publishing (preuzeto 2. 9. 2017).

18. Vučković, Željko. Javne biblioteke i javno znanje. Novi Sad: Biblioteka Matice srpske; Futura publikacije, 2003.

\title{
Literary Field and Public Libraries in Serbia
}

\author{
Summary \\ This paper deals with the relationship between the field of literature in Bourdieu's sense of the word and the \\ activities of public libraries in Serbia, in historical perspective and contemporary moment. Studying the phenomenon \\ of literary work (without entering into the problem of validation and/or division between high and low, i.e. trivial \\ literature), and the development of the public libraries in Serbia, the authors try to show their close connection. It is \\ being observed through the structure of public library collections and the relations between different factors in the \\ literary field (writers, readers, publishers). The explanation of this deep connection could be found in the definition \\ of a public library and its functions as well as in the structure of its users. It is shown that promotional activities, \\ traditional events and publishing activity all have their basis in the field of literature. The educational structure of \\ employees and management in the public libraries is examined, and it also testifies to this strong connection. \\ While examining the abovementioned aspects of the relation between literature and public libraries, the authors \\ consulted selected references, web and social media pages of the public libraries, data from the Department for \\ Research and Development of the Library System - Parent Department of the National Library of Serbia, as well as \\ many colleagues from the public libraries and the field of literature. Dealing with the relationship between literature \\ and the public libraries in Serbia, in historical perspective and today, the authors did not intent to show that the \\ public libraries were one of the factors in the field of literature, understood in Bourdieu's sense of the word, but this \\ conclusion arose from their research. In this context, the task of the public libraries should be to take advantage \\ of this status, not to deny it, because the opportunities it offers, especially in the aspects of presentation and \\ popularization, can provide the visibility of other activities of the libraries to the widest range of their present and \\ future users.
}

Keywords: field of literature, public libraries, literary work, library collections, promotional activities, traditional events, publishing acitivity, users, library staff, Serbia 